\title{
Pineapple: Potential Source of Proteolytic Enzymes for Degumming of Raw Silk
}

ISSN: 2637-7659

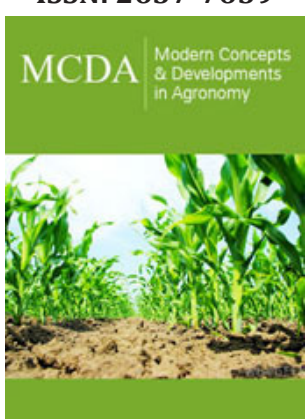

*Corresponding author: Premalatha Shetty, SDM Centre for Research in Ayurveda and Allied Sciences, Department of Biotechnology \& Microbiology, India

Submission: 糊 May 08, 2019

Published: 侽 May 16, 2019

Volume 4 - Issue 2

How to cite this article: Premalatha $S$, Vishwanatha U, Bhagyashree M, Sindhuja R, Surya M, et al. Pineapple: Potential Source of Proteolytic Enzymes for Degumming of Raw Silk. Mod Concep Dev Agrono.4(2). MCDA.000584.2019. DOI: 10.31031/MCDA.2019.04.000585

Copyright@ Premalatha Shetty, This article is distributed under the terms of the Creative Commons Attribution 4.0 International License, which permits unrestricted use and redistribution provided that the original author and source are credited.

\section{Premalatha Shetty *1, Bhagyashree Madanthyar ${ }^{2}$,Sindhuja Ramasubramanian ${ }^{3}$, Surya Malickal ${ }^{3}$, Lakshmi Devi Ramachandran ${ }^{3}$, Vishwanatha Udupi ${ }^{1}$}

${ }^{1}$ Sri Dharmasthala Manjunatheshwara Centre for Research in Ayurveda and Allied Sciences, Udupi, Karnataka, India

${ }^{2}$ Sri Dharmasthala Manjunatheshwara College, PG Department of Chemistry, Ujire, Karnataka ${ }^{3} \mathrm{CMR}$ Institute of Technology, Bangalore, Karnataka, India

\begin{abstract}
Pineapple is a well-known reservoir of proteases. Treatment of silk skeins with pineapple juice resulted in degumming of the fibers leading to unmasking of the lustrous inner layer. The juice obtained from raw pineapple was subjected to concentration by saturation with $85 \%$ ammonium sulfate. The proteolytic activity of the juice as well as the concentrate was found to effectively degum the skein. The proteases were optimally active at $\mathrm{pH} 6.6$, and $50-55{ }^{\circ} \mathrm{C}$. Treatment of the skein with $5 \mathrm{U}$ of proteolytic activity at $50{ }^{\circ} \mathrm{C}$ and $\mathrm{pH} 6.6$ for $120 \mathrm{~min}$ resulted in weight loss to an extent of $17-18.5 \%$. Release of peptides and amino acids, arginine, histidine and aromatic amino acids was monitored during the process of degumming. The rate of release of peptides and amino acids was relatively higher till 90-120min, reducing thereafter. The enzymatically degummed skeins were found to be more lustrous in comparison to untreated skeins. Conventionally, raw silk skeins are chemically treated to impart luster to the fiber. Enzymatically degummed fibers displayed smoother texture and improved stretch ability in comparison to chemically decoated skeins. Use of pineapple in silk manufacture may boost the agronomy in tropical regions where it is grown extensively.
\end{abstract}

Keywords: Degumming; Silk skein; Silk proteins; Pineapple juice; Proteolytic activity; Luster; Amino acids

Abbreviation: TLC: Thin Layer Chromatography

\section{Introduction}

Papaya, pineapple and melons are known to be reservoirs of protease enzymes. Pineapple (Ananus comosus) is a fruit crop of commercial importance cultivated across the globe. The production of the fruit worldwide is reported to be around $1.95 \times 10^{7}$ tons per annum (agriexchange.apeda.gov.in/Market\%20profile//one/PINEAPPLE.aspx). Bromelain, a group of proteolytic enzymes obtained from pineapple fruits is well documented for its therapeutic applications such as reversible inhibition of platelet aggregation, anti-inflammatory agents, enhancement of drug absorption, digestive aids etc. [1-4]. Raw pineapple and stem of pineapple are known to be rich in proteolytic enzymes. Eight proteolytic components have been reported in stem extracts along with peroxidases and protease inhibitors. Pineapple proteases are also employed in brewing and meat tenderization processes [5-8]. Use of pineapple extract while cooking Oak Tassar cocoons has been carried out by Laishram Rup Chandra Das of Manipur university. However, not much literature is available on the work, and hence an elaborate study on use of pineapple proteases in degumming of silk may be promising for farmers as well as biotechnology industries. Much acclaimed for its lustrous and tensile properties, silk is mainly obtained from the cocoons of the larvae of the mulberry silkworm Bombyx mori. During its maturation period from egg to moth, the larvae are guarded safe inside the cocoon which is made of the raw silk fiber secreted from its glands. The raw silk in its natural form contains two different proteins Sericin and Fibroin. Sericin constitutes the outer non-continuous inelastic layer (20\%-30\%).

The inner elastic core consists of the protein fibroin which is responsible for sheen and mechanical strength of silk fibers. Raw silk is therefore processed to remove the outer layer. Both the layers being proteinaceous by nature, it is difficult to separate them effectively. The key amino acid units in both the components vary to a significant extent, thereby providing 
a basis for separation by biochemical mechanisms. The reports on amino acid composition of silk proteins are in concurrence in claiming that serine is the major amino acid present in sericin. Glycine, threonine, alanine, acidic and basic amino acids are the other major amino acids found in sericin. Alanine and glycine constitute around $70 \%$ of the total amino acids present in fibroin [9-11]. Sericin layer is composed of three layers. Kunz [12] report that the outer most and intermediate layers are rich in serine, threonine, glycine and aspartic acid. The middle layer has higher content of tryptophan. The solubility of these layers in water varies. Outermost layer is soluble in water, while the inner most layer adjacent to the fibroin core is the least soluble.

Molecular weight of the sericin recovered from silk wastewaters ranges from 40-176kDa [13]. Apart from its luster, the fibroin layer is known for its elasticity and tensile strength. Interest in proteins from natural sources is gaining popularity for use as biomaterials. The possibility of exploiting the high mechanical strength and biocompatibility of silk proteins in biomedical/therapeutic applications is gaining impetus [14-16]. Outer sericin layer of the raw silk has to be removed for its use in textiles and biomaterials. Traditional method of degumming involves use of detergents at high temperature and alkaline $\mathrm{pH}$ to emulsify sericin residues. The method has been found to affect the textile properties of the fabric along with release of detergent effluent in environment. Various commercially available proteolytic enzymes, lipases and bacterial proteases are therefore, being explored for degumming [17-19]. Possibility of using protease rich plant extracts in degumming of raw silk fiber needs to be considered. In the present investigation, an attempt was made to screen the degumming efficacy of various fruit extracts. Conditions were optimized for decoating of the raw silk fibers with raw pineapple juice. The kinetics of deproteinization was studied.

\section{Material and Methods}

\section{Materials}

All the chemicals and reagents used were of analytical grade. Raw silk fibers obtained from silkworm (Bombyx mori) and reeled into bundles weighing approximately $1 \mathrm{~g}$ each (skeins) / rolled into compact bundles weighing around $5 \mathrm{~g}$ each (twisted yarns) were gifted by CENTRAL SILK TEXTILE RESEARCH INSTITUTE (CSTRI), Bangalore. Sulphorhodamine B and Silica gel $60 \mathrm{~F}_{254}$ plates were procured from MERCK, Germany and SIGMA-ALDRICH,China respectively.

\section{Fruit juices}

Mango (alphonso), watermelon and musk melon were purchased from local market. Pineapples (raw and ripe) were obtained from the local farm. The fruits were peeled and seeds (if present) were removed. The fruit slices were then blended using a mixer. The filtrate was centrifuged at $5000 \mathrm{rpm}$ for $10 \mathrm{~min}$ and the supernatant was used as crude extract.

\section{Assay of protease activity}

Sample, $0.1 \mathrm{ml}$ was incubated with $1.2 \mathrm{ml}$ of Casein $(0.5 \% \mathrm{w} / \mathrm{v})$ in $25 \mathrm{mM}$ phosphate buffer, $\mathrm{pH} 6.6$ for $30 \mathrm{~min}$ at $37^{\circ} \mathrm{C}$. Equal volume of 3\%Trichloro acetic acid was added and centrifuged at $10000 \mathrm{rpm}$ for $10 \mathrm{~min}$. To $0.3 \mathrm{ml}$ of the appropriately diluted supernatant, $0.75 \mathrm{ml} 0.5 \mathrm{M}$ sodium carbonate was added followed by addition of $0.125 \mathrm{ml}$ of $0.4 \mathrm{~N}$ Folin-Ciocalteau regent. The absorbance was read at $650 \mathrm{~nm}$. Tyrosine was used as the standard. Micromole of tyrosine released in one minute under the defined conditions is considered as one unit of activity.

\section{Characterization of the enzyme}

a) Optimum $\mathrm{pH}$ was determined by incubating the enzyme in the substrate solution prepared in buffers ranging from $\mathrm{pH}$ values of 5-7.5.

b) Optimum temperature was measured by incubating the enzyme with substrate at $\mathrm{pH} 6.6$ at temperatures ranging from 30 ${ }^{\circ}-70{ }^{\circ} \mathrm{C}$ for $45 \mathrm{~min}$.

c) The pH stability was studied by incubating the enzyme at various $\mathrm{pH}$ values ranging from $\mathrm{pH} 3.5$ to $\mathrm{pH} 7.5$ for a period of $1 \mathrm{~h}$. Appropriate dilution of the enzyme was incubated with the substrate in $0.1 \mathrm{M}$ substrate at $37^{\circ} \mathrm{C}$ and assayed.

\section{Degumming of the skein with the fruit juices}

The skein was weighed to the fourth decimal place. It was washed in tap water and dried and weighed. Weight of each washed silk skein was approximately around $1 \pm 0.05 \mathrm{~g}$. The skein was immersed in $15 \mathrm{ml}$ of the juice diluted to $30 \mathrm{ml}$ with $\mathrm{D} / \mathrm{W}$ at $29 \pm 1^{\circ} \mathrm{C}$ for $16 \mathrm{~h}$. After incubation the processed silk was taken out and washed under tap water. Care was taken not to tangle the silk. The skeins were air dried in shade and weighed to determine the extent of degumming.

\section{Optimization of conditions for degumming}

For all the degumming experiments, enzyme dosage mentioned is as per the activity assayed at $37{ }^{\circ} \mathrm{C}, \mathrm{pH} 6.6$ unless mentioned otherwise. Each skein was incubated with $4 \mathrm{U}$ of enzyme in $30 \mathrm{ml}$ of $50 \mathrm{mM}$ phosphate buffer, pH 6.6 at $50{ }^{\circ} \mathrm{C}$, unless mentioned otherwise. Weight lost due to degumming was recorded for each skein.

\section{Optimization of pH}

Skeins were incubated with the enzyme in $50 \mathrm{mM}$ acetate/ phosphate buffers at various $\mathrm{pH}$ values for $150 \mathrm{~min}$.

\section{Opimization of enzyme dosage}

The skein was degummed with 7, 4, 2.5 and 1.5 units of activity for $150 \mathrm{~min}$.

\section{Optimization of temperature}

The skeins were treated with the enzyme at temperatures ranging from ambient to $70{ }^{\circ} \mathrm{C}$ for $150 \mathrm{~min}$.

\section{Optimization of time}

Effect of time was studied by incubating the skein for various time periods ranging from $0.5-6 \mathrm{~h}$. 


\section{Concentration of the enzyme}

The juice was subjected to precipitation with ammonium sulfate at $0-85 \%$ saturation. The precipitate was dissolved and dilaysed against $0.1 \%$ sodium chloride solution containing $0.5 \mathrm{mM}$ DTT. The dialysate was stored at $-20^{\circ} \mathrm{C}$.

\section{Kinetics of degumming}

The skein was incubated with $5 \mathrm{U}$ in $25 \mathrm{ml}$ of $50 \mathrm{mM}$ phosphate buffer, $\mathrm{pH} 6.6$ for time periods ranging from $0-3 \mathrm{~h}$ at $50{ }^{\circ} \mathrm{C}$. The solution (hydrolysate) containing the released peptides/amino acids collected at different time intervals was further analysed.

\section{Estimation of release of proteins/peptides}

Estimation of peptides/proteins was carried out by Biuret method using Bovine serum albumin as standard.

\section{Estimation of amino acids}

Amino acids released into the solution were measured using Ninhydrin reagent. Alanine was used as the standard.

\section{Estimation aromatic amino acids}

Aromatic amino acid content was quantified using FolinCiocalteau reagent. To $0.125 \mathrm{ml}$ of the appropriately diluted sample, $0.375 \mathrm{ml}$ of diluted FC reagent was added followed by addition of $0.5 \mathrm{ml} \mathrm{Na}_{2} \mathrm{CO}_{3}$. Absorbance was read after incubation in dark for $90 \mathrm{~min}$. The method was calibrated using tryptophan.

\section{Estimation of arginine}

To $0.5 \mathrm{ml}$ of the sample, $0.1 \mathrm{ml}$ each of $10 \% \mathrm{NaOH}$ and $\alpha$-Naphthol $(\mathrm{mg} / \mathrm{ml})$ was added. After $5 \mathrm{~min}$ of incubation, $0.1 \mathrm{ml}$ of $0.5 \%$ Sodium hypochlorite was added. After $1 \mathrm{~min}$ of reaction, $0.2 \mathrm{ml}$ of urea (20\%, w/v) was added [20]. Absorbance was read at $520 \mathrm{~nm}$.

\section{Estimation of release of histidine and tyrosine}

Pauly's reagent which is used for detection of Histidine and Tyrosine in chromatographic methods was modified for quantitation of these amino acids (http://www.onlinebiologynotes.com/paulystest-objective-principle-reagents-procedure-and-result/). To $0.4 \mathrm{ml}$ of test sample, $0.64 \mathrm{ml}$ of sulphanilic acid-Sodium nitrite mixture (equal volumes of $0.9 \%$ Sulphanilic acid in $1 \mathrm{~N} \mathrm{HCl}$ and $5 \%$ nitrite) and $0.16 \mathrm{ml}$ of $10 \% \mathrm{Na}_{2} \mathrm{CO}_{3}$ was added. Absorbance was read at $410 \mathrm{~nm}$. Histidine was employed as standard. The method was found to be linear in the range of 2-15 micrograms.

\section{Thin layer chromatography}

Amino acid mixtures were prepared at a concentration of $16 \mathrm{mg}$ each per $\mathrm{ml}$ and 8-10 $\mu \mathrm{g}$ each of the amino acids was applied on Silica gel plate (Merck). Hydrolysates obtained from skeins treated with the enzyme at $0,60,120$ and $180 \mathrm{~min}$, was concentrated 25 times by evaporating it in a boiling water bath to dryness. The sample was reconstituted in $20 \mu \mathrm{l}$ of $\mathrm{D} / \mathrm{W}$ and $12 \mu \mathrm{l}$ was spotted onto the plate. Chromatography was performed in Butanol: Acetic acid: Water system (3:1:1) for $8 \mathrm{~h}$. Ninhydrin reagent was used for detection.

\section{Degumming by traditional (chemical) method}

The skein was dispensed into $30 \mathrm{ml}$ of solution containing 501 soap bar (yellow colored), $0.5 \% \mathrm{w} / \mathrm{v}$ in $\mathrm{Na}_{2} \mathrm{CO}_{3}(0.1 \%, \mathrm{w} / \mathrm{v})$ at 40 ${ }^{\circ} \mathrm{C}$. The temperature was then raised to $92{ }^{\circ} \mathrm{C}$ within $15 \mathrm{~min}$ and maintained further for a period of $45 \mathrm{~min}$ at $92 \pm 1{ }^{\circ} \mathrm{C}$. The skein was removed, washed with hot water $\left(60-70^{\circ} \mathrm{C}\right)$, followed by cold water wash and then dried in shade.

\section{Uptake of dyes by the enzyme treated skein}

Sulphorhodamine B $0.057 \%$ in $1 \%$ acetic acid was diluted 40 times with $\mathrm{D} / \mathrm{W}$ and $50 \mathrm{ml}$ of the dye solution was added to $1 \mathrm{~g}$ of the skein. After $30 \mathrm{~min}$ of incubation on a shaker at $50 \mathrm{rpm}$, the skeins were removed and the solution which drained out of the suspended skeins was pooled with the respective unabsorbed fraction. Based on the absorbance at $578 \mathrm{~nm}$, \%age uptake of the dye was calculated.

\section{Testing of strength and elasticity}

The strength and stretchability of enzymatically degummed silk were compared to that of traditionally degummed silk in CSTRI, Bangalore using the INSTRON 550R Computer interfaced strength tester to assess the tensile strength and elongation property of the silk yarns. The yarns were subjected to enzymatic decoating process $(5 \mathrm{U} / \mathrm{g})$. The samples treated by both chemical and enzymatic methods were re-reeled and made into ten revolutions and the circumference was measured separately. Each sample was then sectioned in to ten parts and subjected to strength test and elongation analysis.

\section{Results and Discussion}

Presence of proteases in various fruits is well documented. Endopeptidase belonging to the family of cysteine proteases are found in abundance in fruits such as papaya and pineapple, and their applications in medical and food industries is well documented [2,21-23]. Crude extracts of watermelon, raw mango, muskmelon, and papaya, moderately ripe and raw pineapple were employed to assess their ability to degum raw silk $(20 \mathrm{ml}$ juice per skein, $16 \mathrm{~h}$ at $29 \pm 1{ }^{\circ} \mathrm{C}$ ) and the \% weight loss was found to be around 1.9, 2.8, 4.1, 5.9, 11.6 and 19.2 respectively. Most of these fruit proteases are reportedly not specific in their action. However, Murachi and Neurath [24] have reported that the stem bromelain acted on the Arg-Ala bond of glucagon, while the Arg-Arg and Arg-Lys bonds remained intact. The study also showed that papain and bromelain exhibited differential activity towards various substrates. This implies that relative specificities of these enzymes are not the same. Degumming to an extent of $20 \%$ (weight loss) is required to confer satisfactory luster to the fibers. Proteolytic activity of the raw and ripe pineapple juice (inclusive of core) was found to be around 0.44 and $0.4 \mathrm{U} / \mathrm{ml}$ respectively. The $\mathrm{pH}$ values of ripe and raw fruit juices were around 3.3-3.5 and 3.7-3.9 respectively. As the degumming efficiency was found to be higher, raw pineapple juice was employed for further studies. The proteolytic activity of the juice was characterized with casein as substrate and the results are presented in Figure 1. 


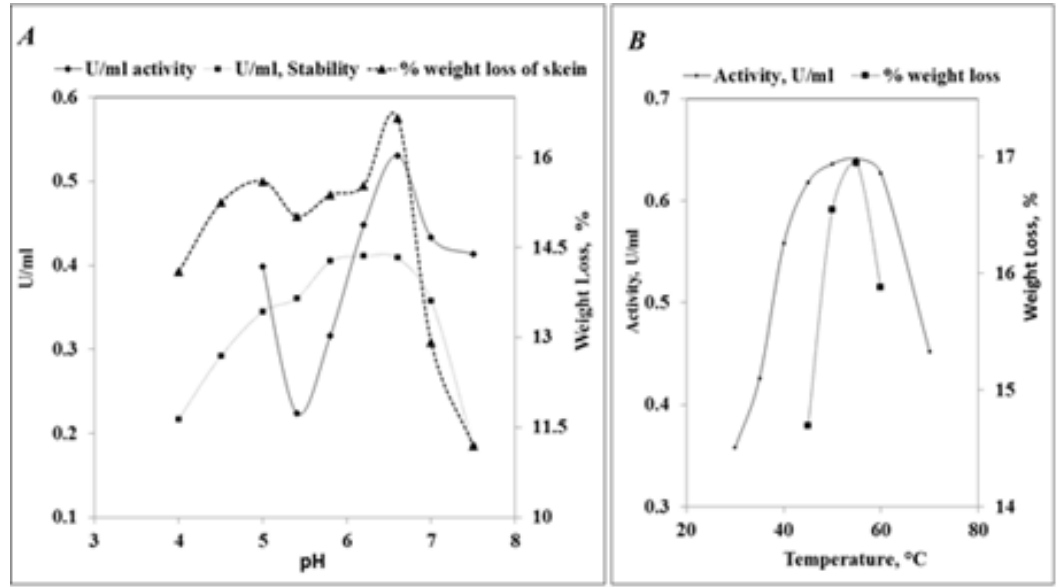

Figure 1: Effect of $\mathrm{pH}$ and temperature on proteolytic action of the juice.

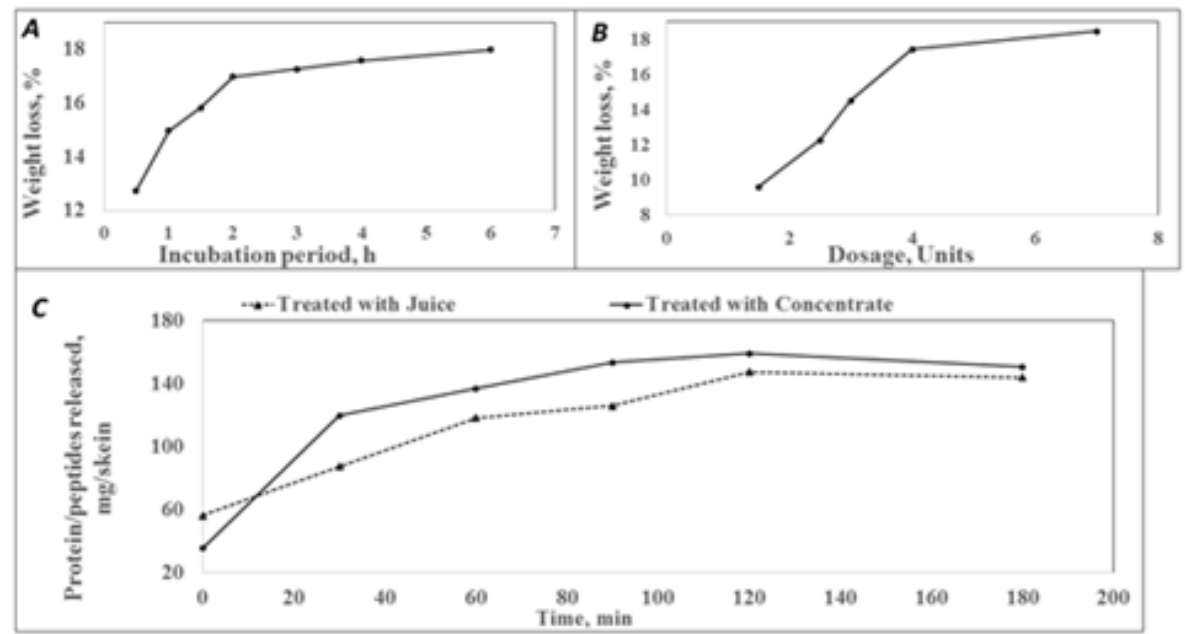

Figure 2: Optimization of Time and enzyme units for degumming and kinetics of release of peptides/proteins.

The activity of the juice was optimum at $\mathrm{pH}$ of 6.6. Activity could not be assessed at lower $\mathrm{pH}$ values as the substrate tended to precipitate at the acidic side of the $\mathrm{pH}$ curve. The activity which was around $0.4 \mathrm{U} / \mathrm{ml}$ at $\mathrm{pH} 5$ decreased to around $0.22 \mathrm{U} / \mathrm{ml}$ at $\mathrm{pH}$ 5.4, followed by an increase reaching to an optimum at $\mathrm{pH} 6.6$, thereby indicating exhibition of two $\mathrm{pH}$ optima values. It could be due to the presence of various isoforms of proteases which are known to exist in pineapple [7]. Degumming of the silk also showed similar trend with maximum weight loss at pH 6.6 (Figure 1A). The enzyme was maximally stable in the $\mathrm{pH}$ range of 5.8-6.6 retaining around $84 \%$ of its activity at $\mathrm{pH}$ 5. Further study on degumming of the skeins was therefore carried out at $\mathrm{pH} 6.6$ to determine the dosage of enzyme per skein. The temperature activity curve was broader with the enzyme being optimally active in the range of 45 ${ }^{\circ} \mathrm{C}-60{ }^{\circ} \mathrm{C}$ (Figure 1B). Degumming efficiency was highest at $55{ }^{\circ} \mathrm{C}$ accounting for a loss in weight to an extent of $16.9 \%$. Although the optimal temperature was found to be $55^{\circ} \mathrm{C}$, the degumming was carried out at suboptimal temperature of $50{ }^{\circ} \mathrm{C}$ in order to reduce the denaturation of the enzyme on prolonged incubation period employed in the degumming process. Reduction in weight was in proportion to the incubation period up to a period of $2 \mathrm{~h}$ resulting in a weight loss of $17 \%$ at the end of $2 \mathrm{~h}$. Rate of degumming decreased thereafter as seen in Figure 2A. Optimization of enzyme dosage was carried out by employing 1.5 to 7 units of activity per skein. Weight loss to an extent of $17.4 \%$ was observed when the skein was subjected to an enzyme dosage of $4 \mathrm{U}$. Increasing the dosage did not increase degumming to a significant extent. For the juice to be employed on a larger scale, it is preferable to store and transport the enzyme in concentrated form. The juice was concentrated by saturating with $85 \%$ ammonium sulfate. Around $65 \%$ of the activity was recovered in the concentrate. The concentrate and the juice were found to degum the skeins (5U/skein) to an extent of $18.5 \%$ and $17.3 \%$ respectively. Around $14 \mathrm{mg}$ of proteins was found to solubilize into the buffer in control sample wherein the skein was incubated in the buffer for 150 min under similar conditions and a reduction in weight of $1.5 \%$ was noted. The release of amino acids and peptides was monitored over a period of $180 \mathrm{~min}$. Biuret method which is based on the quantification of peptide bonds showed that the skein was degummed to a significant extent within $30 \mathrm{~min}$ of incubation by the concentrate. The concentrate was found to be more effective than the juice. The proteolytic action of the enzyme on the released peptides may be resulting in generation 
of shorter peptides and release of free amino acids. At $0 \mathrm{~min}$, the samples showed presence of 56 and $35 \mathrm{mg}$ of proteins in juice and the concentrate exhibiting $5 \mathrm{U}$ of activity, respectively. At the end of $2 \mathrm{~h}$, the degumming of one skein released around $90 \mathrm{mg}$ and $125 \mathrm{mg}$ of proteins (total of $145-160 \mathrm{mg}$ ) into the hydrolysates as shown in Figure 2C.

It must be noted that the degumming of the skein by both the juice and concentrate resulted in reduction of the weight of each skein by $170-180 \mathrm{mg}$. Ninhydrin reagent reacts with the free alpha amino groups and hence detects the presence of not only amino acids, but also the alpha amino ends of peptides. Shorter peptides are, therefore, likely to respond to the reagent, albeit to a lesser extent. The amino acid and peptide content of juice was found to be around $3.5 \mathrm{mg}$ at $0 \mathrm{~min}$, which remained steady for $30 \mathrm{~min}$, increasing thereafter to around $10 \mathrm{mg}$ by the end of $120 \mathrm{~min}$ indicating release of amino acids or peptides from the skein due to protease action. Sericin, the outer coat of silk is reported to contain basic amino acids. Thus, the kinetics of release of arginine containing peptides was studied. The reaction mixture showed presence of a total of $1.2 \mathrm{mg}$ of arginine in the juice at $0 \mathrm{~min}$ and the concentration increased to $2.67 \mathrm{mg}$ at $90 \mathrm{~min}$ of incubation indicating release of arginine or arginine containing peptides from the skein due to the action of proteases in the juice. Pauly's method which measures the tyrosine and Histidine residues based on diazotization reaction showed that histidine and tyrosine content increased from $0.98 \mathrm{mg}$ at $0 \mathrm{~min}$ to $2.72 \mathrm{mg}$ at $120 \mathrm{~min}$. Folin-Lowry's method for estimation of phenolic compounds was employed to measure the amount of aromatic amino acids released due to proteolytic activity of the juice.

The aromatic amino acids and other phenolic compounds amounting to around $2.1 \mathrm{mg}$ was measured at $0 \mathrm{~min}$. An amount of around $2.6 \mathrm{mg}$ of aromatic amino acids/peptides was released from the skein by enzymatic activity in $90 \mathrm{~min}$ (total $4.6 \mathrm{mg}$ ). Release of aromatic residues continued thereafter resulting in total amount of $5.4 \mathrm{mg}$ at the end of $3 \mathrm{~h}$. This could be either due to the action of proteases on the released peptides resulting in generation of free aromatic residues or the possibility of continued degumming affecting the inner layer which perhaps is relatively richer in aromatic amino acids, necessitating the degumming period to be restricted to $120-150 \mathrm{~min}$. Proteolytic action of the concentrate resulted in increase in the amount of peptides and amino acids from $1 \mathrm{mg}$ at $0 \mathrm{~min}$ to around $10.4 \mathrm{mg}$ at $120 \mathrm{~min}$ and, 10.9 at $180 \mathrm{~min}$. Release of arginine containing peptides resulted in an increase from $0.14 \mathrm{mg}$ at $0 \mathrm{~min}$ to $1.1 \mathrm{mg}$ at $120 \mathrm{~min}$ of incubation, steadying thereafter yielding around $1.2 \mathrm{mg}$ of arginine containing peptides at the end of $3 \mathrm{~h}$ of incubation. Release of aromatic amino acids using Folin's reagent as well as release of Histidine and tyrosine as measured by Pauly's method followed similar trend wherein the rate of release of these groups decreased after 120min. Release of alpha amino/ aromatic/ histidine and tyrosine amino acids or peptides containing these groups by the juice proteases followed a pattern as seen in Figure 3. The rate of increase of these residues was found to be slow in the initial 30-60 min, followed by a relatively sharper increase until $90 \mathrm{~min}$. Degumming by proteolytic action of the concentrate however, showed that the hydrolytic action of the proteases yielding these groups initiated at a high rate from $0 \mathrm{~min}$ itself and continued at relatively higher rates till 90-120min (Figure 3B). Extent of deproteinization as measured by biuret method showed that there was not a discernible increase in the amount of proteins released after 120min (Figure 2C). Amino acids measured by Folin's and Pauly's methods however, showed that the release of respective amino acids/peptides continued after $120 \mathrm{~min}$, albeit at a slow rate. These results indicate towards the action of endopeptidases on the existing/released proteins or peptides in the hydrolysate. The skeins subjected to enzymatic degumming appeared lustrous.
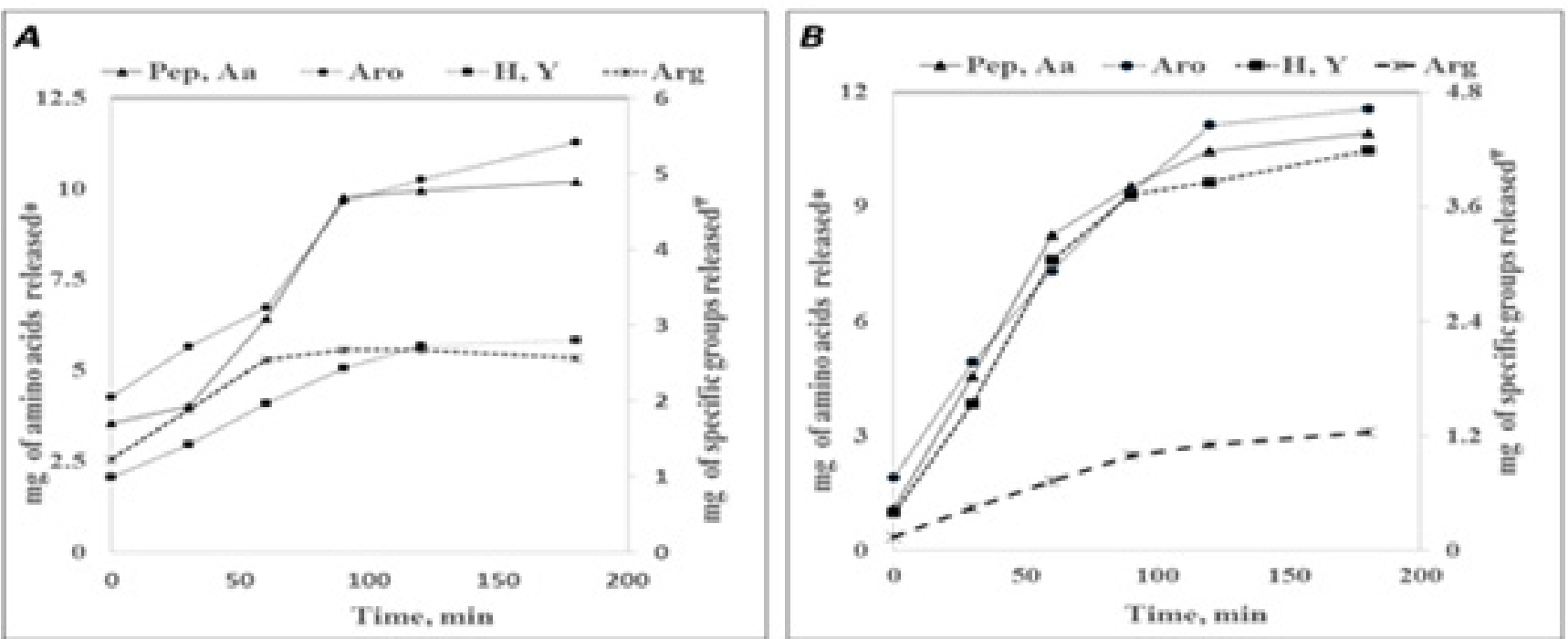

Figure 3: Kinetics of degumming. Release of peptides and amino acids by skeins subjected to proteolytic action of (A): Juice (B): Concentrate; [Pep, Aa: peptides and amino acids; Aro: aromatic amino acids; Arg: Arginine; H, Y: Histidine and Tyrosine]; *peptides and amino acid content measured by Ninhydrin method; $\psi$ Aro/ Arg/ H, Y. 


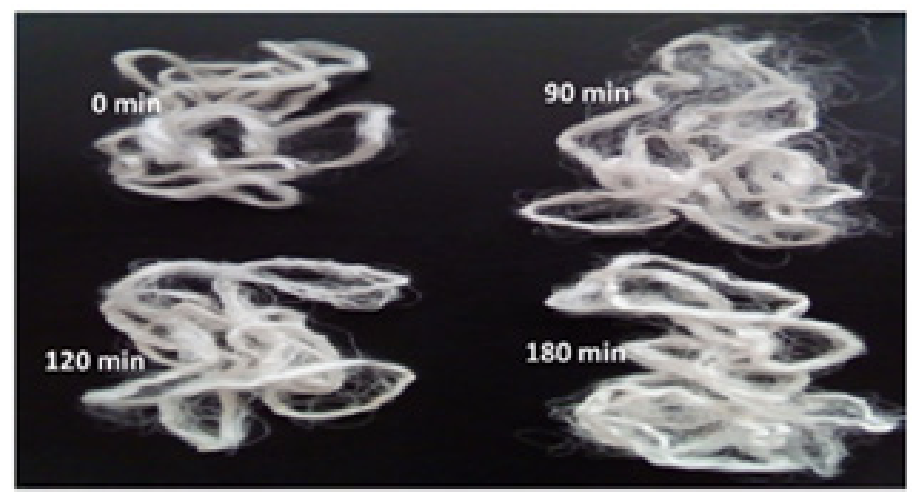

Figure 4: Effect of time on the appearance of skeins treated with the enzyme concentrate.

Skein degummed for $90 \mathrm{~min}$ was less lustrous, while the skein treated for 120 and 180min were found to be comparable in their sheen (Figure 4). All the results indicate that treatment for a period of $120 \mathrm{~min}$ appears to be sufficient for degumming. Sericin is rich in Serine and the inner layer fibroin has high content of Alanine and glycine $[13,25]$. The hydrolysate obtained from skein was therefore, subjected to chromatographic run with these amino acid standards. TLC of the sample collected at 0min, showed trace amount of amino acids/peptides. With time, it was observed that the intensity of the spots representing released products increased. However, these products appeared as smears which could be due to presence of a complex mixture of short peptides and amino acids.
Trace, but increasing amount of amino acid/s with high Rf values was observed as time of incubation progressed (Figure 5). The aromatic amino acids tyrosine and tryptophan correspond to these spots. Leucine is also reported to exhibit same Rf value as that of tryptophan in the same solvent system (http://www.reachdevices. com/TLC_aminoacids.html). The results indicate the possibility of hydrolysis of peptides to a slight extent, resulting in formation of free amino acids. The hydrolysate resulting from the action of enzymes on skein is a mixture of peptides and amino acids. The traditional method employed for degumming which involves use of soap in alkaline conditions resulted in $20 \%$ reduction in the weight of skeins.

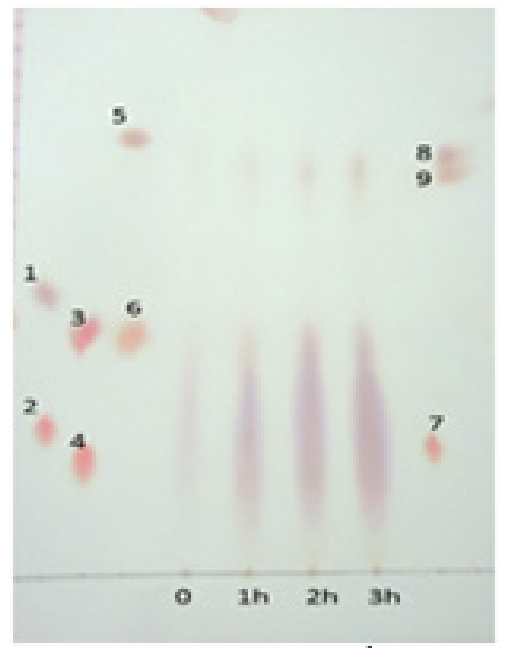

Figure 5: TLC of the products released from the skein due to the proteolytic action of the concentrate 1-Alanine, 2-Arginine; 3-Serine, 4-Lysine; 5- Phenyl alanine, 6-Glycine; 7-His; 8-Tryptophan, 9-Tyrosine.

Although both enzymatically treated and detergent treated skeins were lustrous, the biologically treated skein was smoother in texture than the skein subjected to chemical treatment (Figure 6). Chemically treated skein also displayed slightly frayed appearance. Although the tenacity of enzymatically treated fiber was $1.67 \mathrm{gf} / \mathrm{den}$ and that of traditionally decoated fiber was $1.98 \mathrm{gf} / \mathrm{den}$, the elasticity of biologically treated and chemically treated skeins were $6.7 \%$ and $5.7 \%$ respectively (Table 1 ). Chemically treated samples showed more variation in the values as indicated by the standard deviation. The study on the uptake of the dye Sulphorhodamine B, showed that the skein treated with enzyme concentrate had relatively better capacity to absorb the dye. Uptake of the dye by control and the chemically treated skeins was 53.8 and $58.2 \%$ respectively. The skeins treated with juice and concentrate were able to take up 63.5 and $68.5 \%$ of the dye respectively. During preparation of pineapple juice, the middle portion (core) of the ripe fruit is discarded in general. In the present investigation, juice obtained from the core was employed to assess its degumming efficacy. Treatment of the skeins with 5 and 8 units of activity at pH 6.6 for $150 \mathrm{~min}$ resulted in weight loss of $11 \%$ and $15.1 \%$ respectively. As shown in Figure 5B, 
the silk decoated with the core juice (8U/skein) was more lustrous than the untreated control. However, the luster displayed was less in comparison to the skein treated with the concentrate (5U/skein) which includes the pulp and core enzymes. Optimization of dosage and reaction conditions may yield results equivalent to that of raw pineapple juice. Further studies need to be carried out to use this unused portion of the fruit in order to boost the commercial value of the fruit.

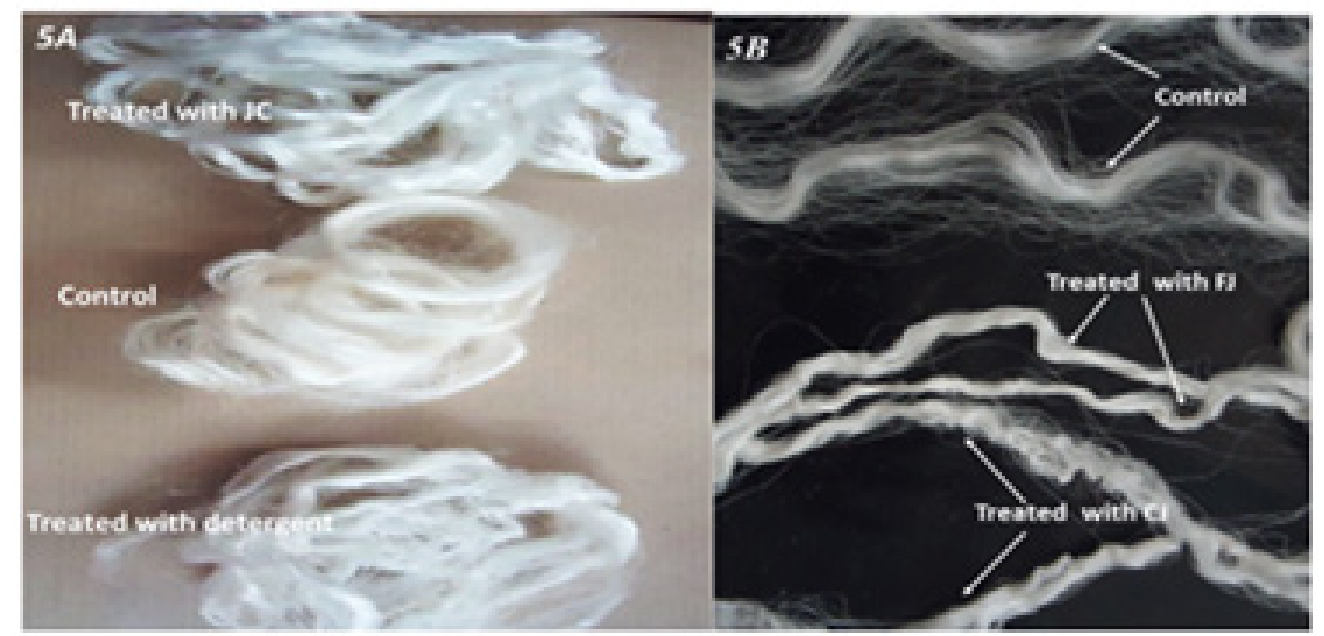

Figure 6: Appearance of skeins treated by chemical and enzymatic methods; JC- Enzyme concentrate; FJ: Fruit juice (5U/ skein); CJ: Core juice (8U/skein).

Table 1: Analysis of Tenacity and Elongation capacity of the treated fibers.

\begin{tabular}{|c|c|c|}
\hline Parameter* & Treated with Concentrate & Treated with Detergent \\
\hline Maximum Load (gf) & $85.97 \pm 5.05$ & $13.43 \pm 1.72$ \\
\hline Extension at Break (mm) & $1.64 \pm 0.1$ & $11.34 \pm 2.6$ \\
\hline Tenacity (gf/den) & $6.72 \pm 0.86$ & $5.9 \pm \pm 0.34$ \\
\hline Elongation (\%) & 5.67 .3 & \\
\hline
\end{tabular}

*Mean of values obtained from 10 parts.

\section{Conclusion}

Promising results were obtained with raw pineapple juice and its concentrate. The skeins were degummed resulting in $17-18.5 \%$ weight loss, consequently improving the luster and texture of raw silk. The enzyme concentrate was found to be more effective than the juice. Treatment of the skein with $5 \mathrm{U}$ of activity for $120 \mathrm{~min}$ was found to yield satisfactory results. Raw pineapple juice/ concentrate can be used as an eco-friendly procedure for degumming of silk. Kinetic studies proved that the resulting hydrolysate can serve as a source of peptides and amino acids. The core of ripe pineapple juice, a byproduct of juice manufacturing process was also found to with: decoat the raw silk fibers.

\section{Acknowledgment}

We thank CSTRI, Bangalore, India for the gift of raw silk and for the analysis of the tensile strength and elongation properties of the fibers. I thank Ms Shwetha, Laboratory technician for her assistance in carrying out the experiments.

\section{References}

1. Chandler DS, Mynott TL (1998) Bromelain protects piglets from diarrhoea caused by oral challenge with K88 positive enterotoxigenic Escherichia coli. Gut 43(2): 196-202.
2. Maurer HR (2001) Bromelain: biochemistry, pharmacology and medical use. Cell Mol Life Sci 58(9): 1234-1245.

3. Barth H, Guseo A, Klein R (2005) In vitro study on the immunological effect of bromelain and trypsin on mononuclear cells from humans. Eur J Med Res 10(8): 325-331.

4. Hale LP, Greer PK, Trinh CT, Gottfried MR (2005) Treatment with oral bromelain decreases colonic inflammation in the IL-10-deficient murine model of inflammatory bowel disease. Clin Immunol 116(2): 135-142.

5. Harrach T, Eckert K, Schulze FK, Nuck R, Grunow D, et al. (1995) Isolation and partial characterization of basic proteinases from stem bromelain. J Protein Chemistry 14(1): 41-52.

6. Doneva M, Miteva D, Dyankova S, Nacheva I, Metodieva P, et al. (2015) Efficiency of plant proteases bromelain and papain on turkey meat tenderness. Biotechnology in Animal Husbandry 31(3): 407-413.

7. Rathnavelu V, Alitheen NB, Sohila S, Kanagesan S, Ramesh R (2016) Potential role of bromelain in clinical and therapeutic applications. Biomed Rep 5(3): 283-288.

8. PAVAN R, JAIN S, SHRADDHA, KUMAR A (2012) PROPERTIES AND THERAPEUTIC APPLICATION OF BROMELAIN: A REVIEW. BIOTECHNOLOGY RESEARCH INTERNATIONAL P. 6.

9. Mondal M, Trivedy K, Kumar SN (2007) The silk proteins, sericin and fibroin in silkworm, Bombyx mori Linn., -a review. Caspian J Env Sci 5(2): 63-76.

10. Kludkiewicz B, Takasu Y, Fedic R, Tamura T, Sehnal F, et al. (2009) Structure and expression of the silk adhesive protein Ser2 in Bombyx mori. Insect Biochem Mol Biol 39(12): 938-946. 
11. Jaramillo QN, Álvarez LC, Restrepo OA (2017) Structural and thermal properties of silk fibroin films obtained from cocoon and waste silk fibers as raw materials. Procedia Engineering 200: 384-388.

12. Kunz RI, Brancalhão RMC, Ribeiro LFC, Natali MRM (2016) Silkworm sericin: properties and biomedical applications. BioMed Res Int 2016:8175701.

13. Capar G, Aygun SS (2015) Characterization of sericin protein recovered from silk wastewaters. Turk Hij Den Biyol Derg, 72(3): 219-234.

14. Joseph B, Raj SJ (2012) Therapeutic applications and properties of silk proteins from Bombyx mori. Frontiers in Life Science 6(3-4): 55-60.

15. Chirila TV, Suzuki S, Bray LJ, Barnett NL, Harkin DG (2013) Evaluation of silk sericin as a biomaterial: in vitro growth of human corneal limbal epithelial cells on Bombyx mori sericin membranes. Progress in biomaterials 2(1):14.

16. Kundu B, Kurland NE, Bano S, Patra C, Engel FB, et al. (2014) Silk proteins for biomedical applications: bioengineering perspectives. Prog Polym Sci 39(2): 251-267.

17. Gulrajani ML, Agarwal R, Grover A, Suri M (2000) Degumming of silk with lipase and protease. Indian Journal of Fiber and Textile Research 25: 69-74.

18. More SV, Khandelwal HB, Joseph MA, Laxman RS (2013) Enzymatic degumming of silk with microbial proteases. Journal of Natural Fibers 10(2): 98-111.
19. More SV, Chavan S, Prabhune AA (2018) Silk degumming and utilization of silk sericin by hydrolysis using alkaline protease from Beauveria $S p$. (MTCC 5184): A green approach. Journal of Natural Fibers 15(3): 373383.

20. Albanese AA, Frankston JE (1945) The colorimetric determination of arginine in protein hydrolysates and human urine. J Biol Chem 159: 185194.

21. Kaneda M, Yonezawa H, Uchikoba T (1997) Purification and some properties of a protease from the sarcocarp of musk melon fruit. Biosci Biotechnol Biochem 61(12): 2100-2102.

22. Yamagata H, Masuzawa T, Nagaoka Y, Ohnishi T, Iwasaki T (1994) Cucumisin, a serine protease from melon fruits, shares structural homology with subtilisin and is generated from a large precursor. J Biol Chem 269(52): 32725-32731.

23. Chitturi S, Gopichand V, Talatam, Vuppu S (2013) Studies on protein content, protease activity, antioxidants potential, melanin composition, glucosinolate and pectin constitution with brief statistical analysis in some medicinally significant fruit peels. Der Pharmacia Lettre 5 (1): 1323.

24. Murachi T, Neurath H (1980) Fractionation and specificity studies on stem bromelain. J Biol Chem 236(1): 99-107.

25. Fedič R, Žurovec M, Sehnal F (2003) Correlation between fibroin amino acid sequence and physical silk properties. J Biol Chem 278: 3525535264. 